\title{
DEVELOPMENT OF THE REGULATION RELATED TO OBLIGATORY BEQUEST (WASIAT WAJIBAH) IN INDONESIAN ISLAMIC INHERITANCE LAW SYSTEM ${ }^{*}$
}

\author{
Haniah Ilhami** \\ Department of Islamic Law, Faculty of Law, Universitas Gadjah Mada, Yogyakarta \\ Jalan Sosio Yustisia No. 1 Bulaksumur, Sleman, D.I. Yogyakarta 55281
}

\begin{abstract}
This research examine the development of regulation of wasiat wajibah, its legal consideration and the implementation in Religious Court. This research founds the addition of legatee of wasiat wajibah which are children born out of wedlock, children in unregistered marriage, and stepchildren. The consideration of those addition are relation between Inheritance Law with Marriage Law System, relation of legal rights and responsibilities, status of children through Constitutional Court Decision No.46/PUU-VIII/2010, the application of Qiyas method, and the objective of justice in Inheritance law. In Religious Court, judges only give wasiat wajibah to children born out of wedlock.
\end{abstract}

Keywords: wasiat wajibah, child born out of wedlock, children born in unregistered marriage, and step children.

\section{Intisari}

Penelitian ini meneliti perkembangan pengaturan wasiat wajibah dalam Sistem Hukum Kewarisan Islam di Indonesia, pertimbangan hukumnya, dan implementasinya pada Pengadilan Agama. Penelitian menemukan penambahan kelompok penerima wasiat wajibah yaitu anak yang lahir di luar perkawinan, anak yang lahir di dalam perkawinan tidak tercatat, dan anak tiri yang dipelihara sejak kecil. Pertimbangan hukum yang digunakan adalah keterkaitan Sistem Hukum Waris dengan Sistem Hukum Perkawinan, hubungan Hak dan Kewajiban, status anak dalam Putusan MK Nomor 46/PUU-VIII/2010, penggunaan metode Qiyas, dan tujuan keadilan dalam hukum waris. Dalam implementasinya, Pengadilan Agama hanya memberikan wasiat wajibah kepada anak yang lahir di luar perkawinan

Kata Kunci: wasiat wajibah, anak zina, anak yang lahir dalam perkawinan tidak tercatat, dan anak tiri.

\section{Pokok Muatan}

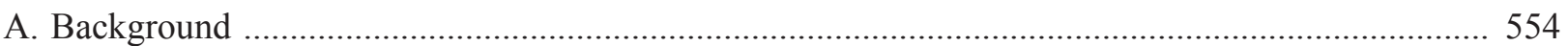

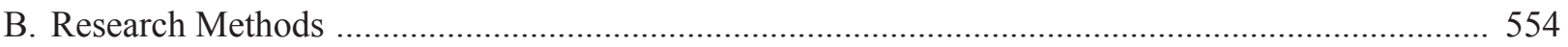

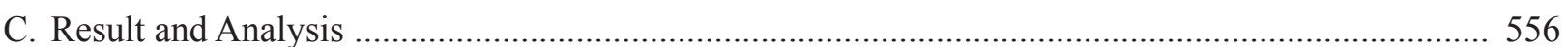

1. The Development of Regulations about Wasiat Wajibah in Indonesian Islamic Inheritance

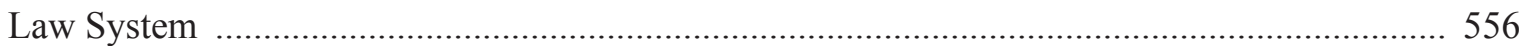

2. Legal Considerations in the Development of Regulations on Wasiat Wajibah ......................... 558

3. Implementation of The Development of Regulations of Wasiat Wajibah in the Decision and Decree of Religious Court in Indonesia ............................................................................... 561

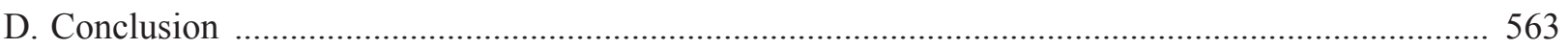

\footnotetext{
Research Result by the Faculty of Law, Universitas Gadjah Mada, Yogyakarta in 2015
}

Corespondence address: haniah.ilhami@gmail.com 


\section{A. Background}

Obligatory Bequest or wasiat wajibah (hereinafter referred to as wasiat wajibah) is a new concept in Islamic inheritance law in Indonesia, which was first introduced formally through Presidential Instruction No. 1 of 1991 concerning the Compilation of Islamic Law or Kompilasi Hukum Islam (hereinafter referred to as KHI). The terminology of wasiat wajibah in KHI originally referred to the provision of wasiat wajibah in Egyptian legal system, which formally enacted into positive law through the Egyptian Wills Act $1946 .{ }^{1}$ However, in the basic concept, wasiat wajibah in KHI regulate a completely different thing with the provisions in Egyptian legal system. wasiat wajibah in KHI accomodates the actual practices of Indonesian society that affected by the provisions of customary law and the predominance in society family relationships, particularly regarding to the position of adopted children. Based on this condition, KHI arranged special provisions for distribution of property between the adopted child and the adoptive parents in the Islamic inheritance system by using the institution wasiat wajibah. Institutionalization of wasiat wajibah formally was objected to maintain and accommodate the aspirations of law and public justice, as well as making wasiat wajibah as a social engineering tools for Indonesian Muslim community. ${ }^{2}$

Although normatively been determined that wasiat wajibah in the KHI regulated only for the adopted child and adoptive parents, in the development, provision wasiat wajibah has expanded. Through several jurisprudence of the Supreme Court in 1995 and 1999, the judge extending the provision that wasiat wajibah may also be given to the heirs who are not Muslims. ${ }^{3}$
Furthermore, wasiat wajibah was reconstructured through Fatwa of The Indonesian Council of Ulama or majelis Ulama Indonesia (herinafter referred to as MUI) in $2012^{4}$ and Circular Letter of the Supreme Court (SEMA) ${ }^{5}$ Through those regulations, wasiat wajibah that previously can only be given to the adopted child and the adoptive parents, as well as to the heirs who are not Muslim, currently it can also be given to the children which was born out of wedlock from their biological father and stepchildren who have nurtured since their childhood.

Based on those conditions, the legal problems in this research are the development of the regulation of wasiat wajibah in Islamic Inheritance Law System in Indonesia and its legal considerations, and the implementation of that development in the Religious Court decisions.

\section{B. Research Methods}

This research combine both of normative legal research (literature research) and empirical legal research (field research). Under these conditions, this research examine the development of some of the regulations of wasiat wajibah in the Indonesian legal system and its practices and implementations of the Religious Courts.

\section{Literature Research}

Literature research conducted in 2 (two) phases, before and after the field research. Literature research conducted prior to field research aims to provide the basic concepts and guides for researcher to carry out the next stage of research. Literature research conducted after the field research aims to analyse the results from the respondents and interviewees in accordance with the principles of Islamic inheritance law. In more detail, the literature research that has been done is as follows:

\footnotetext{
Destri Budi Nugraheni, et al., 2009, Pengaturan dan Implementasi Wasiat Wajibah, Research Report, Faculty of Law UGM, Yogyakarta, pp. 11-12.

Muhammad Daud Ali, 1993, Hukum Islam Pengantar Ilmu Hukum dan Tata Hukum Islam di Indonesia, Raja Grafindo Persada, Jakarta, hlm. 268.

See Supreme Court Decision Number 368.K/AG/1995 andSupreme Court Decision Number 51.K/AG/1999.

Fatwa of the Indonesian Council of Ulama No. 11 of 2012 concerning The Position of Child Born Out of Wedlock and His Legal Treatment. See Supreme Court Circular Letter No. 07 of 2012 concerning the Legal Formulation of the Plenary Meeting Room of the Supreme Court as Court Guidelines.
} 
a) Research tools. This literature research uses general secondary data include official documents, the results of previous research, and other library materials; b) Research material. Literature research consists of 3 (three) materials, which are the primary legal materials, secondary legal materials and tertiary legal materials, with systematics; primary legal materials are any regulations closely related to the study, include, laws and regulations: a) Law No. 1 of 1974 concerning Marriage; b) Law No. 7 of 1989 concerning Religious Courts as last amended by Law No. 50 of 2009 concerning the Third Amendment of Law No. 7 of 1989 concerning Religious Courts; c) Presidential Instruction No. 1 of 1991 concerning the Compilation of Islamic Law.

Decision of the Administrative Officer, Decree, Circular Letter, and other binding legal materials, include: a) Decree of the Chairman of the Supreme Court Number: KMA/032/SK/IV/2006 on 4 April 2006 concerning the Enforcement of Book II Guidelines for Administration of Justice in Court; b) Fatwa The Indonesian Council of Ulama No.5 of 2005 regarding Inheritance of Different Religions; c) Fatwa of The Indonesian Council of Ulama No. 11 of 2012 concerning The Position of Child Born Out of Wedlock and His Legal Treatment d) Supreme Court Circular Letter No. 07 of 2012 concerning the Legal Formulation of the Plenary Meeting Room of the Supreme Court as Court Guidelines; e) Supreme Court Circular Letter No. 04 of 2014 concerning the Legal Formulation of the Plenary Meeting Room of the Supreme Court as Court Guidelines; and f) Supreme Court Circular Letter No. 05 of 2014 concerning the Legal Formulation of the Plenary Meeting Room of the Supreme Court as Court Guidelines. Religious Courts' Decisions: a) Constitutional Court Decision No. 46/PUU-VIII/2010; b) Supreme Court Decision No. 368K/AG/1995; c) Supreme Court Decision No. 51.K/AG/1999; d) Supreme Court Decision No. 489K/AG/2011; e) Surabaya PTA decision No. 104/Pd.G/2011/PTA.Sby; f) Decree No. 0156/ Pdt.P/2013/PA.JS; g) Decree No. 0078/Pdt.P/2014/ PA.Mgt; h) Decree No. 0011/Pdt.P/2015/PA.Kdr; i) No. 40/Pdt.P/2012/PA.Clg; j) Decision No. 297/ Pdt.G/2010/PA.Mlg.

Secondary legal materials, all materials that explain the primary legal material,include: (1) The books that discuss Islamic marriage law in general and wasiat wajibah in particular; (2) Other results of legal research and opinion of legal experts to discuss related issues; (3) Magazines, journals and newspaper articles related to the related problem, both nationally and internationally; (4) The writings contained in the internet sites related to the problem. Tertiary legal materials, any legal materials that give instructions and explanations of the primary and secondary legal materials, which include: (1) legal dictionary; (2) indonesian dictionary; (3) encyclopaedia.

\section{Analysis Method}

Research done by find, select, analyse, collect, and compare all legal materials related to the research problem, to make the conclusions related to the problem. The research used a qualitative analysis method, which collected all the data, selected, and studied as a whole so that can give a comprehensive description.

\section{Field Research}

Field research conducted through the Focus Group Discussion by inviting religious court judges as expert speakers. Speakers who participated in the discussion were selected based on the following considerations: (1) Affordability of Research Area, they are 1 (one) Judge from each Religious Courts in Special Region of Yogyakarta, include the Religious Court in Bantul, Religious Court in Wonosari, Religious Court in Wates, and 1 (one) High Religious Court of Yogyakarta; (2) The involvement of speakers both in the decision to wasiat wajibah or other related decisions, they are 1 (one) Judge from each Religious Courts in Surakarta and Religious Court in Purwodadi; (3) The involvement speakers to provide contributions to the development of Islamic law in Indonesia through his legal considerations in Decisions, who is a Judge of High Religious Court in Jambi. In addition, this research included 1 (one) speaker 
from the Indonesian Council of Ulama in the area of Yogyakarta. From the results of field research, the data analysis is done by processed and analysed directly using the descriptive qualitative method. The process is conducted into a broad description, it concludes the results comprehensively.

\section{Result and Analysis}

1. The Development of Regulations about Wasiat Wajibah in Indonesian Islamic Inheritance Law System

This research found that the development of regulations about wasiat wajibah in Indonesian Islamic Inheritance Law System is divided into several periods as follows:

\section{a. Regulations about Wasiat Wajibah in Period of 1991}

Period of 1991 is an emergence period of wasiat wajibah in Indonesian Islamic Inheritance Law System through Presidential Instruction No. 11991 about the Compilation of Islamic Law. Wasiat wajibah defined as any actions taken by an authority or a judge to force the decision to give an obligatory bequest from the deceased to be given to certain people in certain circumstances. ${ }^{6}$ KHI then regulate the terms and conditions of wasiat wajibah through article 209 as follows:

1) The property of inherintance of an adopted child is distributed under Article 176 to Article 193 mentioned above, while to his adopting parents who hasn't received any will/testament, shall be given wasiat wajibah as much as $1 / 3$ the net property of inherintance.

2) The adopted children who hasn't received any will/testament, shall also be given wasiat wajibah as much as $1 / 3$ the net property of inherintance of their adoptive parents.

Under this provision, KHI gives the limitations on testator, legatee, and the maximum limit of wasiat wajibah.

b. Regulations about Wasiat Wajibah in Period of 1995 up to 2012

The development of regulations on wasiat wajibah in this period is the expansion of the provision about the parties that could receive wasiat wajibah (also know as legatee of wasiat wajibah), specifically related to heirs that has a different religion with the deceased. Differences of religion in Islamic inheritance law is a prohibitive factor for someone to become the heir and receive the distribution of property of inheritance. In this period, this provision was excluded through jurisprudence in some Religious Court's decision which are:

1) Jurisprudence that granted wasiat wajibah for the child who is not Muslim, through the Supreme Court Decision No. 368.K/AG/1995;

2) Jurisprudence that granted $w a-$ siat wajibah for the Substitution Heir who is not a Muslim, through the Supreme Court Decision No. 51.K/AG/1999 in September 29, 1999;

3) Jurisprudence that granted wasiat wajibah for the wife who is not Muslim, through the Supreme Court Decision No. 16.K/ AG/2010 on April 30, 2010.

Not only through jurisprudence, the provision that granted wasiat wajibah for different religious' heir is also reinforced by the Fatwa of the Indonesian Council 
of Ulama No. 5/MUNASVII/MUI/9/2005 concerning Inheritance Different religion. The fatwa states that:

a. Islamic law does not give the right to inherit each other between people of different religions (Muslims and nonMuslims)

b. Distribution of preperty among people of different religions can only be done in the form of grants, wills, and gifts.

The provisions in this Fatwa strengthens provisions regarding the regulation in KHI about the religion requirements for an heir, and at the same time also implements the jurisprudence of the Supreme Court regarding the provision wasiat wajibah for heirs who are not Muslims.

\section{c. Regulations about Wasiat Wajibah in Period of 2012 until Now}

The development of regulations on wasiat wajibah in this period is determined by the re-expansion of the provisions about the parties that could receive wasiat wajibah (also know as legatee of wasiat wajibah), which can also be given to children born out of wedlock, a child born in unregistered marriage, and stepchildren who have nurtured since his childhood. In detail, the development in this period is described as follows:

\section{1) The Development Wasiat Wajibah related to Children Born Out of Wedlock}

KHI stipulates that a legitimate child is a those who were born from the legal marriage, and or those who were born from the legal external insemination from the sperm and ovum of the husband and the wife who are legally married and born by the wife. ${ }^{7}$ While the legal marriage is a marriage conducted according to the laws of each religion. ${ }^{8}$ The illegitimate children is those who does those qualification above, or often called as children born out of wedlock.

The regulation of wasiat wajibah related to the children born out of wedlock can be seen in Fatwa of The Indonesian Council of Ulama No. 11 of 2012 concerning The Position of Child Born Out of Wedlock and His Legal Treatment. That fatwa defines a child as a result of zina (adultery) is any children who was born as a result of sexual intercourse outside of legitimate marriage under the terms of religion. ${ }^{9}$ This children doesn't have any legal relation to their biological father, include the relation of nasab, Guardian of Marriage, relation of inheritance, an nafaqah. This children only have those kind of relations with their mother and her family. ${ }^{10}$ Under this provision, the children born out of wedlock is not the heir of their biological father and was not entitled to inherit the property of inheritance of the biological father.

Furthermore, fatwa also defines that wasiat wajibah is the government policy to oblige any biological father to make a will/testament for his biological children to give an estate after his death. ${ }^{11}$ This provision was

Number 1 General Provisions Fatwa of The Indonesian Council of Ulama No. 11 of 2012 concerning The Position of Child Born Out of Wedlock and His Legal Treatment.

10 Number 1 and Number 2 General Provisions Fatwa of The Indonesian Council of Ulama No. 11 of 2012 concerning The Position of Child Born Out of Wedlock and His Legal Treatment.

11 Number 4 General Provisions Fatwa of The Indonesian Council of Ulama No. 11 of 2012 concerning The Position of Child Born Out of Wedlock and His Legal Treatment. 
reinforced by the provision that the Government is authorized to impose penalties "Ta'zir" to the adulterer man which caused the birth of a child by obliging them to provide a property of inheritance after he passed away. ${ }^{12}$ This provisions shows the developments of wasiat wajibah that may also be given to children born out of wedlock

2) The Development Wasiat Wajibah related to A Child Born in Unregistered Marriage

The development of regulations on wasiat wajibah for a child born in unregistered marriage was initiated in the National Working Meeting with the Board of the Supreme Court that formulates the summaries of Group Discussion in Religious Court (Commission II). The summaries was strengthened through the Supreme Court Circular Letter No. 07 of 2012 concerning the Legal Formulation of the Plenary Meeting Room of the Supreme Court as Court Guidelines. One of the provisions in the discussion is the status of children born in unregistered marriage. A children who were in unregistered marriage, has the right to earn a living as well as wasiat wajibah from their father ${ }^{13}$ Therefore, children born in unregistered marriage may apply for Approval of the Children to the Religious Court, because children have rights to know and gain legal certainty about their parents. ${ }^{14}$ Under this provision, wasiat wajibah has been expanded its provision of legatee by adding marriage
3) The Development Wasiat Wajibah about Stepchildren

The development of regulations wasiat wajibah for stepchildren also initiated through the National Working Meeting of the Supreme Court in 2012. In the the summaries of Group Discussion in Religious Court (Commission II), stated that the stepchildren who have nurtured since his childhood is not as heir, but can be granted by wasiat wajibah. This provision is reinforced by the Supreme Court Circular Letter No. 07 year 2012 concerning the Legal Formulation of the Plenary Meeting Room of the Supreme Court as Court Guidelines. Under this provision, wasiat wajibah has been expanded its provision of legatee by adding the stepchildren who have nurtured since his childhood

Based on these results above, it can be concluded that wasiat wajibah is expanded broadly since it was first introduced through KHI, specifically the provisions of legatee which are now may be given to to 5 (five) groups:

a. Adopted child and the adopting parents;

b. Heirs that hindered by the religious differences;

c. Children born out of wedlock;

d. Children born in unregistered marriage; and

e. Stepchildren who have nurtured since his childhood.

\section{Legal Considerations in the Development} of Regulations on Wasiat Wajibah

This study focuses on the development wasiat wajibah in the period of 2012 until today, because the research about the development of

\footnotetext{
Number 5 General Provisions Fatwa of The Indonesian Council of Ulama No. 11 of 2012 concerning The Position of Child Born Out of Wedlock and His Legal Treatment.

13 Number 4 Material Law Technical Judicial summaries of Group Discussion in Religious Court (Commission II).

14 Ibid.
} 
wasiat wajibah specifically for Heirs that hindered by the religious differences, has been carried out by previous research. ${ }^{15}$ Legal considerations in the development of the provision wasiat wajibah in the period of 2012 is as follows:

a. Legal considerations about Wasiat Wajibah for Children Born Out of Wedlock and a Child Born in Unregistered Marriage

Based on this research, consideration of granting wasiat wajibah for children born out of wedlock and a child born in unregistered marriage using the same reasons:

1) The Relation between Legal Rights and Legal Responsibilities as The Basis of Inheritance

The relation of rights and obligations is a form of relationship that is based on the principle of Responsibility. Principle of Responsibility in Islamic law commands that any person who performs any kind of acts shall be liable for any form and the consequences of his actions. ${ }^{16}$ Based on this principle, the responsibility exist at the time of the actions, intentionally or not. Related to the provision wasiat wajibah for children born out of wedlock, then if a man a woman perfomed any sexual actions which caused a children from those actions, at the same time, the responsibilities of parents arised, although formally, there were no any legal relations between them. The same consideration alse performed for children who were born in unregistered marriage. Any Parents who have children, remains bound on the obligation to provide a living and raise her children, even though they are not legally binding as husband and wife.

2) The Development Status of Children that Born Out of Wedlock through Constitutional Court Decision No. 46/ PUU-VIII/2010

Constitutional Court Decision No. 46 / PUU-VIII / 2010 has expanded the definition and on the status of legitimate children that had been prevailing in the Islamic marriage law in Indonesia. Legitimate children was initially interpreted into 2 (two) groups: ${ }^{17}$

a) Children who were born from the legal marriage, and

b) Children who were born from the legal external insemination from the sperm and ovum of the husband and the wife aho are legally married and born by the wife.

Through its Decision, the Constitutional Court created a new norm that regulates the status of children born outside of marriage which are:

A child born out of wedlock must have civil relationship with his/her mother and his/ her mother's family as well as with a man as his/her father which can be proven based on science and technology and/or other evidence that such child has blood relation, including civil relationship with his/her father's family. ${ }^{18}$

Based on this decision, when previously children born outside

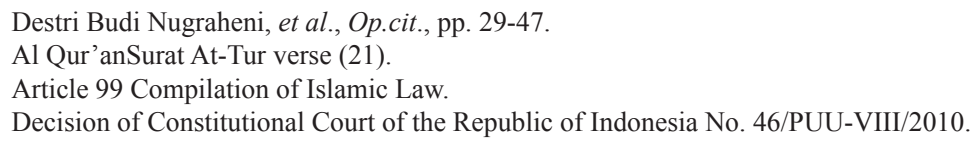


of wedlock is not an heir of their biological father, currently they can be considered as the heirs and received the distribution of preperty of inheritance of their biological father; as long as it meet the rquirements of proving the existence of a blood relationship.

This provision strengthened through Fatwa of The Indonesian Council of Ulama No. 11 of 2012 concerning The Position of Child Born Out of Wedlock and His Legal Treatment which granted wasiat wajibah to the Child Born Out of Wedlock from the property of his biological father. The Fatwa commands that as a responsibility, the biological parents who performed any sexual actions outside the legal marriage can be sentenced within 2 (two) forms of punishment, the punishment in the criminal law and in the civil law. ${ }^{19}$

The penalties of $T a$ 'zir stipulated in the MUI Fatwa No. 11 of 2012 is the punishment of the civil law, that obliges the biological father to: ${ }^{20}$

a) Provide the Living of his shildren, and

b) Provide a property of inheritance after he passed away through wasiat wajibah.

This punishment is to provide legal protection and justice for the children of their biological father, to give responsibility to the biological father for his actions that led to the birth of a child out of wedlock, and creating a deterrent for others not to perform the same illegal actions. ${ }^{21}$

3) The Consideration of Wasiat Wajibah as a Method to Achieve The Justice in Islamic Inheritance Law

Philosophically, the concept wasiat wajibah in fact intends creating fairness and give protection to all those who need their rights protected. ${ }^{22}$ Justice itself is divided into 2 (two) forms, Legal Justice and Social Justice: ${ }^{23}$ Legal Justice is the justice that achieved if fulfilled the provisions of the law without considering factors other than the law itself. Social Justice is the justice based on real conditions in society, not merely to comply with only the formal enactment Law itself. The regulation of wasiat wajibah intends of the achievement of social justice.

b. Legal Consideration of Wasiat Wajibah for Stepchildren

Consideration of wasiat wajibah for step children is based on 3 (three) consideration, the legal relationship of rights and obligations as the basis of the inheritance, the consideration that wasiat wajibah is as a method to achieve the justice in Islamic Inheritance Law, and the application of Qiyas for determining the position of stepchildren. Related to the consideration of the legal relationship of rights and obligations as the basis for the inheritance, the real position of stepchildren is that they do not have any blood-relations with his stepparents. However, because in the factual conditions those stepchildren have nurtured since his

Legal Provisions Number 5 Fatwa of The Indonesian Council of Ulama No. 11 of 2012 concerning The Position of Child Born Out of Wedlock and His Legal Treatment.

Ibid.

21 A. Mukti Arrto, 2013, Hukuman Ta'zir Mewajibkan Ayah Biologis memberi Bagian dari Harta Waris untuk Anak Luar Nikah dan Penyelesaiannya di Pengadilan Agama, unpublished article, Ambon, p. 7.

22 Opinion by Dr. H. A. Mukti Arto., S.H., M.H. in Focus Group Discussion, held on Saturday, 25 April 2015, Faculty of Law UGM.

23 Opinion by Dr. Drs. H. Makhrus, S.H., M.Hum. in Focus Group Discussion held on Saturday, 25 April 2015, Faculty of Law UGM. 
childhood and also get a living from their stepchildren, therefore their position may be equated with the biological children.

The application of Qiyas for determining the position of stepchildren shows in determining the position of stepchildren as the legatee of wasiat wajibah. The method of Qiyas compares the position of stepchildren to the position of adopted children, on the basis of similarities between the two, which are:

a. Both do not have a bloodrelation with the adopting parents or step-parents;

b. Both are not an heir because they do not meet requirements of heir;

c. In factual conditions in our society, both are be accepted and treated the same as biological children.

From the similiarities, then the position of stepchildren can be equated with the position adopted children so as to it may also be given the same rights of the wasiat wajibah.

Qiyas method is also used to compare the position of stepchildren with the provision of inheritance to relatives. ${ }^{24}$ Relatives who have no right of inheritance can still get parts of property through the provision of gift which is limited to one third of the property of inheritance. Related the position of stepchildren, the stepchildren may also consider as relatives because in the reality of family life, step children has been an integral part in the family. Based on this condition, when their step parents passed away, stepchild entitled to part of the property given by the institution wasiat wajibah.
3. Implementation of The Development of Regulations of Wasiat Wajibah in the Decision and Decree of Religious Court in Indonesia

The development wasiat wajibah that expand the provision about the parties that could receive wasiat wajibah (also know as legatee of wasiat wajibah) through some regulations above, in practice is not widely implemented in Religious Court ${ }^{25}$ This is mainly because that those developments is newly regulated and very dependent to the dynamics of inheritance disputes submitted to the Religious Court. In several decisions, the implementation of the development of regulations wasiat wajibah can be seen as follows:

a. Implementation of the Development related to Children Born Out of Wedlock

The provision wasiat wajibah for children born out of wedlock (Decisions referred to using the term Anak hasil Zina) has been carried out by the Religious Court judges. In general, judges using some basic laws in its legal considerations which are: ${ }^{26}$

1) Law No. 4 of 1979 concerning the Welfare of Children;

2) Law No. 39 of 1999 concerning Human Rights;

3) Law No. 23 of 2002 concerning Child Protection;

4) Supreme Court Circular Letter No. 07 of 2012 concerning the Legal Formulation of the Plenary Meeting Room of the Supreme Court as Court Guidelines;

5) Constitutional Court Decision No. 46/ PUU-VIII/2010;

6) Fatwa of The Indonesian Council of Ulama No. 11 of 2012 concerning The Position of Child Born Out of Wedlock and His Legal Treatment.

Al Qur'an Surat An Nisa verse (8).

Opinion by judges in Focus Group Discussion with theme "Perkembangan Wasiat Wajibah dan Perbuatan Melawan Hukum pada Sengketa Waris Orang-Orang Islam", held on Saturday, 25 April 2015, Faculty of Law UGM.

26 In legal considerations in Decree of Religious Coury No. 0156/Pdt.P/2013/PA JS, No. 0078/Pdt.P/2014/PA.Mgt, and No.0011/Pdt.P/2015/ PA.Kdr. 
In general, the legal reasoning used by the panel of judges always consider the benefit of children and focused on the fact that children born out of wedlock must be free from sin and the burden of the mistakes made by their parents. Therefore, to him shall be given the rights of a child as the rights acquired by the other children, especially the right to make a living and get a share of the inheritance from their biological parents.

Based on some Decree of Religious Court, the study found that the provision wasiat wajibah for children born out of wedlock was not performed on the basis of inheritance dispute or request for decree of heirs. The Decree of Religious Courts that gave wasiat wajibah to children born out of wedlock is done in the form of the Decree of the application about the Origin of the child. This can be seen in 3 (three) determination of the Religious Court, Decree No. 0156/ Pdt.P/2013/PA.JS in South Jakarta Religious Court, Decree No. 078/Pdt.P/2014/PA.Mgt in Magetan Religious Court, and Decreen No. 011/Pdt.P/2015/PA.Kdr in the Kediri Religious Court. All those Decreess based on the Request of the Origin of the Child, which also establishes the position of children born out of wedlock as the recipient wasiat wajibah.

In those Decrees above, they are also differences in the Decree that explicitly mentions to grant the wasiat wajibah for children born out of wedlock. One Decree ${ }^{27}$ explicitly mentioned that:

Declarethat the child (children of Petitioner I and Petitioner II) has a civil relationship with Petitioners I limited to the responsibility of parents to provide his living until he is grown-up and become independent and washiat wajibah maximum 1/3.

The difference things shows in other Decree which is not expressly mention the provision of wasiat wajibah in its decalaration, but only within the legal considerations. Based on this condition, it can be concluded that the development wasiat wajibah for children born out of wedlock has been implemented by the Religious Court.

\section{b. Implementation of the Development of Regulations of Wasiat Wajibah related to the Child Born in Unregistered Marriage}

The provision wasiat wajibah for child born in unregistered marriage or known also know as the term Kawin Sirri, based on this study, found differences between the regulation and theimplementation in Religious Court. Normatively ${ }^{28}$, it is stated that the child born in unregistered marriage, has the right to earn a living and wasiat wajibah from his father. However, in its legal considerations, the judges use different considerations. Judge puts a child born out of wedlock has a different position with the child that born in unregistered marriage. The children that born in unregistered marriage is consider as a Legitimate Child, because their parents factually is legally bound in accordance to the religious provisions. Therefore, this child has a fully civil relationship with his parents, which also means that formally the position of this child is as the heir of his parents, not only as the legatee of wasiat wajibah ${ }^{29}$ This was confirmed by the declaration in Religious Court where a panel using the terminology "Legitimate Child" and not "Biological Child" as used in the Decree of the application about Origin of the child.

See Decree No. 0156/Pdt.P/2013/PA JS.

28 Look the summaries of Group Discussion in Religious Court (Commission II) in the National Working Meeting with the Board of the Supreme Court 2012, strengtened by Supreme Court Circular Letter No. 07 of 2012 concerning the Legal Formulation of the Plenary Meeting Room of the Supreme Court as Court Guidelines.

29 See Consideration in Decree No.0022/Pdt.P/2015/PA.Mgt. 
This difference indicates that the judges has placed children born in unregistered marriage differently compare to the position of children born out of wedlock.

\section{c. Implementation of the Development of Regulations of Wasiat Wajibah related to the Stepchildren}

The provision wasiat wajibah for the stepchildren is about the most recent developments of wasiat wajibah. This study did not find a decision or decree of the Religious Courts tha declaring to grant wasiat wajibah to the stepchildren. The study only found the decree that set the position of stepchildren in the development of Islamic Inheritance law in Indonesia.

The study found that one religious court that grant wasiat wajibah on stepchildren. However, this is due to the step child shall be appointed by the parents as his adopted child. On the Request of adoption, the judges decralaed that in the future, this stepchild may grant wasiat wajibah from his stepfather in his position as the adopted child. ${ }^{30}$

The interesting thing found in the study is the decision of the courts that declare the different thinngs compared to the Regulations of wasiat wajibah. In one of the inheritance dispute, the judges did not put stepchildren as the recipient wasiat wajibah. ${ }^{31}$ In this dispute, there is a deceased who died without leaving any biological children. His heirs are 2 (two) widows, 1 (one) adopted children, and 1 (one) stepchildren. Through the declaration, the judges decided that the widow gets his share as a widow, an adopted child received wasiat wajibah, whereas stepchildren do not get anything because it has no blood relation with the deceased. This decision was not accepted and filed an appeal. The panel of judges in the high religious court evidently agreed with the religious court and upheld the decision which does not provide any portion of the stepchild.

Different things found when this case filed an appeal of this decision to the Supreme Court. ${ }^{32}$ In the declaration, the Supreme Court judges changed the decision of Both Religious Court and High Religious Court by stating that the property of inheritance shall be distributed to the adopted children and stepchildren with equal division. Based on this, the judge has made a new norm that puts stepchild parallel with the adopted child, and provide both the remaining part of the same amount. This Decisions is then filed an Extraordinary Legal Remedy in 2013 in the form of Judicial Review. In the process of judicial review, judges use the same consideration as the Supreme Court. ${ }^{33}$ Based on this, it is seen that the regulation of the position of stepchildren as the recipient wasiat wajibah are not implemented in Religious Court.

\section{Conclusion}

Based on the research that has been done and funded by the Research and Development Center Faculty of Law, Gadjah Mada University, it can be concluded that: Firstly, the regulations of wasiat wajibah is expanded broadly, specifically in the provisions of legatee which are now may be given to to 5 (five) groups, adopted child and the adopting parents, Heirs that hindered by the religious differences, children born out of wedlock, children born in unregistered marriage, and stepchildren who have nurtured since his childhood. Secondly, The consideration of those development are the relation between Inheritance Law System with Marriage Law System, the relation between legal rights and 
legal responsibilities as the basis of inheritance, the development status of children that born out of wedlock through Constitutional Court Decision No. 46/PUU-VIII/2010, the application of Qiyas for determining the position of stepchildren, and the consideration wasiat wajibah as a method to achieve the justice in Islamic Inheritance Law. Thirdly, in court's decision, judges only give wasiat wajibah to children born out of wedlock.

\section{BIBLIOGRAPHY}

\section{A. Books}

Ali, Muhammad Daud, 1993, Hukum Islam Pengantar Ilmu Hukum dan Tata Hukum Islam di Indonesia, Raja Grafindo Persada, Jakarta.

Bisri, Cik Hasan, et al., 1999, KHI dan Peradilan Agama dalam Sistem Hukum Nasional, Logos Wacana Ilmu, Jakarta.

Huberman, Matthew B. Miles and A. Michael, 1992, Analisis Data Kualitatif, Universitas Indonesia Press, Jakarta.

Lukito, Ratno, 2008, Hukum Islam dan Realita Sosial, Fakultas Syariah Universitas Islam Negeri Sunan Kalijaga, Yogyakarta.

Muzarie, Mukhlisin, 2002, Kontroversi Perkawinan Wanita Hamil, Pustaka Dinamika, Yogyakarta.

Nugraheni, Destri Budi Nugraheni dan Haniah Ilhami, 2014, Pembaruan Hukum Kewarisan Islam di Indonesia, Gadjah Mada University Press, Yogyakarta.

\section{B. Research Report}

Nugraheni, Destri Budi, et al., 2009, Pengaturan dan Implementasi Wasiat Wajibah, Result Report, Faculty of Law UGM.

\section{Papers}

Arto, A. Mukti Arto, "Diskusi Hukum Putusan Mahkamah Konstitusi No. 46/PUU-VIII/2010 tanggal 27 Februari 2012 tentang Pengubahan Pasal 43 UUP tentang Hubungan Perdata Anak dengan Ayah Biologisnya", Paper, Diskusi hukum Hakim Pengadilan Tinggi Agama Ambon dan Pengadilan Agama Ambon bersama Pejabat Kepaniteraan,
Auditorium Pengadilan Tinggi Agama Ambon, 16 March 2012,

\section{Journal Articles}

Manan, Abdul, "Beberapa Masalah Hukum tentang Wasiat dan Permasalahannya dalam Konteks Kewenangan Peradilan Agama", Mimbar Hukum Aktualisasi Hukum Islam, No. 38, Year IX, 1998.

\section{E. Internet Articles}

Arto, A, Mukti, "Hukuman Ta'zir Mewajibkan Ayah Biologis Memberi Bagian dari Harta Waris untuk Anak Luar Nikah dan Penyelesaiannya di Pengadilan Agama", http://badilag.net/ artikel/14566-tazir-ayah-biologis-a-wasiatwajibah-oleh-a-mukti-arto--192.html, accessed on 26 April 2015.

\section{F. Court Decisions}

Decision of Constitutional Court of the Republic of Indonesia No. 46/PUU-VIII/2010.

Decision of Supreme Court of the Republic of Indonesia No. 368.K/AG/1995.

Decision of Supreme Court of the Republic of Indonesia No. 51.K/AG/1999.

Decision of Supreme Court of the Republic of Indonesia No. 489 K/AG/2011.

Decision of Religious High Court of Surabaya No. 104 / Pd t . G/ 2011 / PTA. Sby.

Decree of Religious Court of Jakarta Selatan No. 0156/Pdt.P/2013/PA JS.

Decree of Religious Court of Magetan No. 0078/ Pdt.P/2014/PA.Mgt.

Decree of Religious Court of Kediri No. 0011/ Pdt.P/2015/PA.Kdr. 
Decree of Religious Court of Cilegon No. 40/ Pdt.P/2012/PA.Clg.

Decree of Religious Court of Malang No. 297/ Pdt.G/2010/PA.Mlg.

\section{G. Regulations}

Law No. 1 of 1974 concerning Marriage (State Gazette of the Republic of Indonesia Year 1974 Number 1, Statute to State Gazette of the Republic of Indonesia Number ).
Civil Code of the Republic of Indonesia.

Instruction of President No. 1 of 1991 concerning Compicaltion of Islamic Law.

Supreme Court Circular Letter No. 7 of 2012 concerning the Legal Formulation of the Plenary Meeting Room of the Supreme Court as Court Guidelines.

Fatwa of The Indonesian Council of Ulama No. 11 of 2012 concerning The Position of Child Born Out of Wedlock and His Legal Treatment. 